\title{
Large Serous Cystadenoma in a Postmenopausal Woman: A Case Report
}

\author{
Shikha Bhadoria
}

\begin{abstract}
Serous cyst adenoma is a cystic ovarian tumor containing a serous fluid and a solid-tissue component. This tumor is a benign form, presenting as a cystic unilocular or a multilocular ovarian mass with a thin wall and minimal papillary projections. Giant ovarian tumors have become rare because of the early detection of adnexal pathology with the advent of routine imaging modalities in the recent era of medical practice. In previous studies, large or giant ovarian cysts were described as cysts measuring more than $10 \mathrm{~cm}$ in diameter in a radiological scan or those cysts reaching above the umbilicus. In this study, we report a case of 58-year-old woman who was diagnosed with a right ovarian benign serous cystadenoma measuring $30 \times 26 \times 24 \mathrm{~cm}$ in size with a weight of $5.5 \mathrm{~kg}$.
\end{abstract}

Keywords: Bilateral salpingo-oophorectomy, Computer tomography, Postmenopausal women.

Journal of South Asian Federation of Menopause Societies (2019): 10.5005/jp-journals-10032-1165

\section{INTRODUCTION}

Serous cyst adenoma is a cystic ovarian tumor containing a serous fluid and a solid-tissue component. This tumor is a benign form, presenting as a cystic unilocular or a multilocular ovarian mass with a thin wall and minimal papillary projections. 'Giant ovarian tumors have become rare because of the early detection of adnexal pathology with the advent of routine imaging modalities in the recent era of medical practice. ${ }^{2,3}$ In previous studies, large or giant ovarian cysts were described as cysts measuring more than $10 \mathrm{~cm}$ in diameter in a radiological scan or those cysts reaching above the umbilicus. $^{2}$ Cystadenoma, adenofibroma, and surface papillomas are the benign serous tumors. These tumors occur in about $25 \%$ of all benign ovarian neoplasms and in $58 \%$ of all ovarian serous tumors. ${ }^{3}$ Serous tumors are commonly seen during the reproductive period and $50 \%$ of them occur before the age of 40 years. Most of these cysts are benign, with a chance of malignancy being only $7-13 \%$ in premenopausal and $8-45 \%$ in postmenopausal women. ${ }^{4,5}$ Huge size ovarian serous cystadenomas are rare. In the literature, a few cases of giant ovarian cysts have been mentioned sporadically, primarily in elderly patients.

In this study, we report a case of 58-year-old woman who was diagnosed with a right ovarian benign serous cystadenoma measuring $30 \times 26 \times 24 \mathrm{~cm}$ in size with a weight of $5.5 \mathrm{~kg}$.

\section{Case Description}

A 58-year-old postmenopausal woman with previous 3 LSCS presented with a complaint of a gradual distension of the abdomen from the last 3 months. On general examination, the patient was vitally stable. A per abdominal examination revealed a large abdominal mass corresponding to a 34-weeks gestational-size uterus. The mass was firm in consistency with restricted mobility. A per speculum examination revealed a healthy cervix and vagina. On a per vaginal examination, a mass of 34-weeks gestational size was palpable which was firm to hard in consistency, uterus could not be felt separately, and right-side forniceal tenderness was present. An abdominal ultrasound examination showed a large cystic lesion $(23 \times 18 \mathrm{~cm})$ arising from the pelvis and extending to
Department of Obstetrics and Gynaecology, DY Patil Hospital and Research Centre, Kolhapur, Maharashtra, India

Corresponding Author: Shikha Bhadoria, Department of Obstetrics and Gynaecology, DY Patil Hospital and Research Centre, Kolhapur, Maharashtra, India, Phone: +91 7999490679, e-mail: dr.shikha20@ gmail.com

How to cite this article: Bhadoria S. Large Serous Cystadenoma in a Postmenopausal Woman: A Case Report. J South Asian Feder Menopause Soc 2019;7(1):32-33.

Source of support: Nil

Conflict of interest: None

the epigastric region with thick intenal septae. Contrast enhanced computer tomography of the abdomen and pelvis showed a large hypodense cystic density lesion of $25 \times 23 \times 21 \mathrm{~cm}$, with multiple internal hyperdense septations, the evidence of a cyst adenoma of the ovary. Laboratory tests (including tumor marker CA125) were within normal limits.

The patient underwent an exploratory laparotomy with a right ovarian cystectomy, with total abdominal hysterectomy with left-sided salpingo-oopherectomy done. Intraoperative findings showed a large right ovarian cyst of $32 \times 26 \times 25 \mathrm{~cm}$ seen with a normal-sized uterus with the cystic mass adherent to the omentum; the mass was separated by blunt dissection and sent for frozen section, which was suggestive of a benign serous cystadenoma. A mass of $30 \times 26 \times 24 \mathrm{~cm}$ size with a weight $5.5 \mathrm{~kg}$ was successfully removed. Final impression was suggestive of a benign serous cystadenoma. The postoperative course of the patient was uneventful.

\section{Discussion}

Large/giant ovarian cysts are benign in most of the cases, and histopathologically these cysts are either serous or mucinous. ${ }^{4}$ Serous tumors secrete serous fluids and are originated by an invagination of the surface epithelium of the ovary. Serous tumors are commonly benign (70\%); $5-10 \%$ have borderline malignant potential, and

() The Author(s). 2019 Open Access This article is distributed under the terms of the Creative Commons Attribution 4.0 International License (https://creativecommons. org/licenses/by-nc/4.0/), which permits unrestricted use, distribution, and non-commercial reproduction in any medium, provided you give appropriate credit to the original author(s) and the source, provide a link to the Creative Commons license, and indicate if changes were made. The Creative Commons Public Domain Dedication waiver (http://creativecommons.org/publicdomain/zero/1.0/) applies to the data made available in this article, unless otherwise stated. 


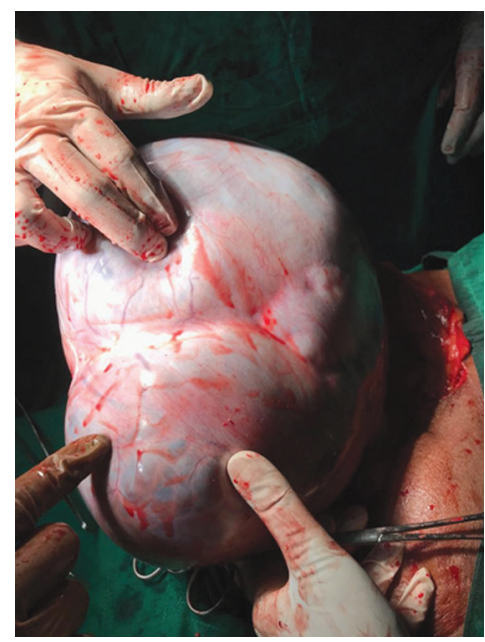

Fig. 1: Gross examination of the right ovarian benign serous cystadenoma

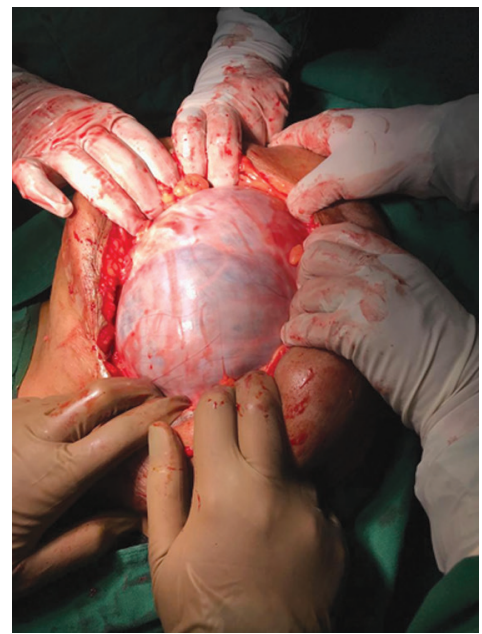

Fig. 2: Gross examination of the right ovarian benign serous cystadenoma

$20-25 \%$ are malignant. Only $10 \%$ cases of all serous tumors are bilateral. $^{3}$

Serous cystadenomas are multilocular. In some instances, they include papillary projections. Giant ovarian serous cyst adenoma is a rare finding. In the literature, a few cases of giant ovarian cysts have been mentioned sporadically and especially in elderly postmenopausal women (Figs. 1 and 2). 2,3

Sharatz et al. reported a case of a 11-year-old, morbidly obese female who presented with left flank pain, nausea, and irregular menses. Various diagnostic procedures suggested a large ovarian cyst, and a surgical resection was performed.
They concluded that histologically, the resected mass was not of tubal origin as suspected, but a serous cystadenoma arising from the ovarian tissue. The patient's two normal, eutopic ovaries were completely uninvolved and unaffected. A tumor arising from the ectopic ovarian tissue of embryological origin seems the most likely explanation. ${ }^{6}$ Mülayim et al. presented a case of 36 -year-old virgin woman (nonmarried) presenting a giant ovarian serous cyst adenoma weighing $9.5 \mathrm{~kg}$. When she was seen first at their outpatient clinic, she looked like a 9-month pregnant woman. Her medical history was normal. She had no serious illness or operation before. On abdominal ultrasound, a giant cyst was found, which encompassed the whole abdomen. At laparotomy, a giant, totally cystic, vascularized, and smooth mass attached to the right ovary was encountered, lying between the symphysis and the xiphoid. A ooferectomy was performed. On the postoperative second day, she was discharged without any problem. Her pathology report disclosed a $35 \times 20 \times 16 \mathrm{~cm}$ serous cyst adenoma weighing $9.5 \mathrm{~kg}^{7}$ Şahin et al. reported a case of a 65 -year-old patient with progressive pelvic pain and postmenopausal vaginal bleeding was evaluated by transvaginal ultrasound, which revealed bilateral adnexal masses measuring $5 \mathrm{~cm}$ in size and a normal uterus with an increased endometrial thickness of $7 \mathrm{~mm}$. Initially the endometrial sampling result was reported as benign. The patient underwent abdominal hysterectomy and bilateral salpingo-oophorectomy and the pathological diagnosis was again benign, with a serous ovarian cystadenoma being found in both ovaries. The pathologist also reported an incidental ectopic adrenal tissue on the wall of the left ovarian cystadenoma. ${ }^{8}$

\section{References}

1. Diamantopoulou S, Sikiotis K, et al. Serous cystadenoma with massive ovarian edema. A case report and review of the literature. Clin Exp Obstet Gynecol 2009;36(1):58-61.

2. Agrawal SP, Rath SK, et al. Large ovarian tumor: a case report. Int J Sci Study 2015; http://www.ijss-sn.com/uploads/2/0/1/5/20153321/ ijss_jun_cr08.pdf.

3. Sujatha VV, Babu SC. Giant ovarian serous cystadenoma in a postmenopausal woman: a case report. Cases J 2009;2:7875. DOI: 10.4076/1757-1626-2-7875.

4. Dey M, Pathak N. Giant serous papillary cystadenoma. Med J Armed Forces India 2011;67(3):272-273. DOI: 10.1016/S0377-1237(11)60059-2.

5. Alobaid A, Memon A, et al. Laparoscopic management of huge ovarian cysts. Obstet Gynecol Int 2013;2013:380854. DOI: $10.1155 / 2013 / 380854$.

6. Sharatz SM, Treviño TA, et al. Giant serous cystadenoma arising from an accessory ovary in a morbidly obese 11-year-old girl: a case report. J Med Case Rep 2008;2:7. DOI: 10.1186/1752-1947-2-7.

7. Mülayim B, Gürakan $\mathrm{H}$, et al. Unaware of a giant serous cyst adenoma: a case report. Arch Gynecol Obstet 2006 Mar;273(6):381-383. DOI: 10.1007/s00404-005-0087-x.

8. Şahin Ç, Taylan E, et al. Ovarian serous cystadenoma with ectopic adrenal tissue in a 65-year-old patient: a case report. Int J Surg Case Rep 2017;33:89-91. DOI: 10.1016/j.ijscr.2017.02.045. 